\title{
Heale jutule pole tõde takistuseks Jan Harold Brunvandi linnalegendid kakskümmend aastat hiljem
}

Eda Kalmre

Nõukogude võimu aastatel oli Eestile naabermaa Soome omamoodi paokil uks maailma, kust vahel ka folkloristide sekka mõni värskendav mõte ja huvitavam raamat sattus. Nüüdseks meie hulgast lahkunud soome folklorist Leea Virtanen (1935-2002) oli inimene, kelle kaudu Jan Harold Brunvandi 1981. aastal ilmunud The Vanishing Hitchhiker (Haihtuv hääletaja) eesti folkloristide töölauale jõudis. Julgen öelda, et see oli üks tollastest järjestikku saadud innustajatest, ${ }^{2}$ mis eesti rahvaluuleuurijaid tänapäeva inimese ja tema maailmas käibiva folklooriga tegelema ärgitas. ${ }^{3}$ Folkloristikas leidsid Jan Harold Brunvandi esimese raamatu lood endale üsna varsti Rootsi, Saksa, Austraalia, Inglise ja Hollandi uurijate kirja pandud analoogid.

Leea Virtaneni 1987. aastal ilmunud raamatu Varastettu isoäiti. Kaupungin kansantarinoita (Varastatud vanaema. Linna rahvajutud) ainesest leiab eesti lugeja palju silmatorkavalt tuttavlikke süžeesid.

Märkimist väärib seegi, et 1982. aastal, aasta pärast Haihtuva hääletaja esmatrüki ilmumist, loodi Rahvusvaheline Tänapäeva Muistendi Uurimise Selts (ISCLR, The International Society for Contemporary Legend Research). 1993. aastaks oli tänapäeva muistendi alane kirjandus juba nii mahukas, et anti välja selle ainevaldkonna bibliograafia (Bennett \& Smith 1993). Rohkem kui kaks aastakümmet väldanud diskussioonid uue žanri ja selle karakteristikate üle on nüüdseks vaibunud, ammendatud aga ei ole kaugeltki kõik teoreetilised teed ega võimalused, mida pakub selle aktuaalse žanriga tegelemine folkloristile.

http://haldjas.folklore.ee/tagused/nr23/brunvand.pdf 
Eda Kalmre

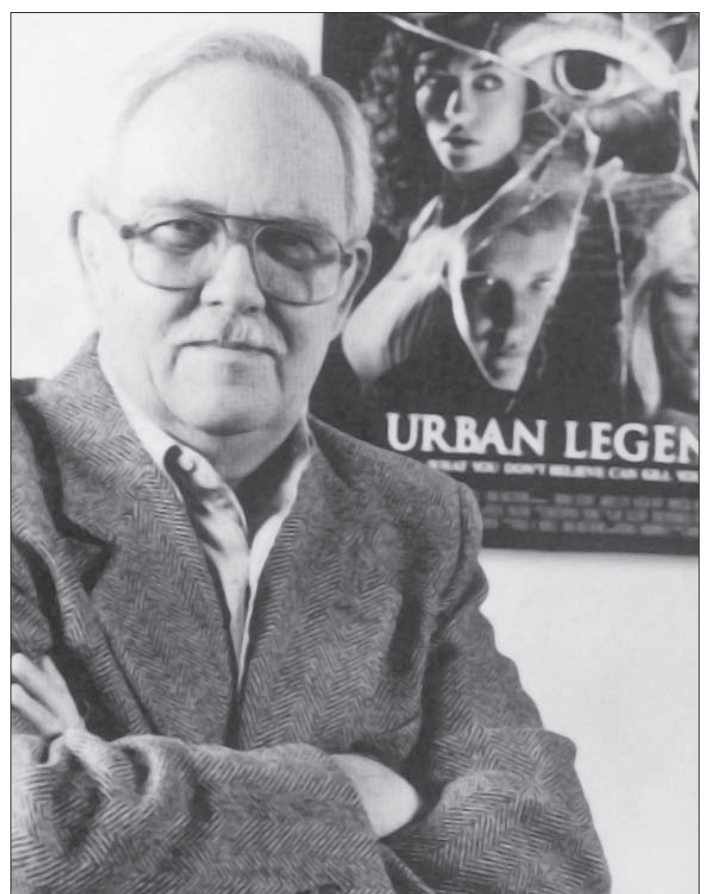

Foto 1. "Linnalegendide isa”, Utah'ülikooli emeriitprofessor Jan Harold Brunvand (sünd 1933).

\section{Jan Harold Brunvandi fenomenist}

23. märtsil 2003 seitsmekümnendat sünnipäeva pidanud Jan Harold Brunvand on üks Ameerika nimekamaid vanema põlve folkloriste. Ta ise peab oluliseks rõhutada oma norra päritolu ja seda, et hääldab oma eesnime Yon. ${ }^{4}$ Doktorikraadini jõudis J. H. Brunvand Indiana ülikoolis, kus ta oli maineka folkloristi Richard M. Dorsoni õpilane. Aastatel 1966-1996 õpetas ta Utah' ülikooli inglise keele osakonnas ja on praegu samas emeriitprofessor.

Kuna Utah' ülikoolis folkloristika eriharu ei olnud, said üliõpilased rahvaluulet õppida vaid valikainena. J. H. Brunvand ise märgib kahetsevalt, et Utah' ülikoolis loetud kursused ei ulatunud kaugemale sissejuhatusest ning Ameerika ja Lääne-Ameerika folkloori, eeskätt ballaadide, rahvalaulude ja rahvajuttude ülevaadetest. 
Oma Utah' ülikooli seinte vahel veidi ühekülgseks jäänud folkloristikarjääri on J. H. Brunvand väga edukalt tasakaalustanud, osaledes aktiivselt Ameerika akadeemilises folkloristikas. Ta toimetas aastatel 1976-1980 folklooriajakirja Journal of American Folklore ja on olnud Ameerika Folkloori Seltsi (American Folklore Society) president. Peale Ameerika Folkloori Seltsi kuulub ta Utah' ja California regionaalsetesse folklooriseltsidesse ning mõistagi ka Rahvusvahelisse Tänapäeva Muistendi Uurimise Seltsi. Tema artikleid on ilmunud paljudes erialaajakirjades.

Jan Harold Brunvandi viimase aja suurematest töödest on väljapaistvamad üliõpilastele mõeldud ameerika folkloori õpik The Study of American Folklore: An Introduction (esmatrükk 1968, 4. trükk 1998) ja folkloorientsüklopeedia American Folklore: An Encyclopedia (1996).

J. H. Brunvandi kui folkloristi ja etnoloogi huvide mitmekülgsusest ja avarusest annavad tunnistust näiteks tema kolm uurimisretke Rumeeniasse ja sealseid majakaunistusi käsitlevad kirjutised. ${ }^{5}$

Utah' ülikooli emeriitprofessorit Jan Harold Brunvandi on mõnikord iseloomustatud kui folkloristi, kes tegi eksemplina käibinud muistendist rahva seas hinnatud kaubaartikli (vt näit Dégh 2001: 45). Tõepoolest on J. H. Brunvand avaldanud aastatel 1981-2002 vähemalt kaheksa laiale lugejaskonnale mõeldud raamatut, millest üks on hiigelraamat linnamuistenditest Too Good to be True (Liiga hea, et olla tõsi 1999) ja teine, Encyclopedia of Urban Legends: ABC-CLIO (2001) pürib lausa teatmeteoseks. Peale selle on ta avaldanud linnamuistendeid käsitlevaid artikleid ja lühemaid kirjutisi.

Kui tahta Jan Harold Brunvandi võrrelda mõne eesti folkloristiga, sobiks selleks Matthias Johann Eisen (1857-1934). Mõlema autori tööd iseloomustavad kirjutiste rahvapärane stiil ja üldist huvi pakkuvad teemad ning väljaannete rohkus. J. H. Brunvand ise ütleb:

Üldiselt on kõik minu linnalegendialased kirjutised valminud töö kõrvalt: alguses kui hobi, hiljem peaaegu kui sundus (või painaja). Ma pean vajalikuks seda sellepärast märkida, et mõned inimesed näivad mõtlevat, et mul on siin mingi suur linnamuistendite uurimise keskus, tegelikult olen siin ainult mina üksinda. ${ }^{6}$ 


\section{Eda Kalmre}

J.H. Brunvandi vaieldamatuks teeneks tuleb pidada seda, et ta sidus tervikuks ja tõi tähelepanu keskmesse jutuainese, mis 20. sajandi teisel poolel meedias ja teadusühiskonnas eriliselt esile kerkis. Kahtlemata on J. H. Brunvandi kirjutised mõjutanud uusi akadeemiliste folkloristide põlvkondi, sundides neid ümber hindama mitmeid varasemaid arusaamu (Dégh 2001: 45). Paljud tema raamatud ja sõnavõtud on aidanud kaasa tänapäeva ühiskonnas (ja eriti meedias) valdavaks saanud muistenditest rääkimise ja kirjutamise diskursusele.

Suurema osa J. H. Brunvandi kogutud ainese kohta ei paindu keel ütlema sõna muistend, sest selle sõna tüvi osutab justkui millelegi, mis leidis aset ammu-ammu. Küllap sellepärast on otsetõlkeline ja rahvapärane linnalegend meedias ja ka teadusterminoloogias sünonüümsena käibele läinud. Žanriliselt võiks suure osa niisugusest ainesest paigutada ka tõestisündinud loona räägitud uudise, kõmujutu, pajatuse, naljandi vms valdkonda. Tõepoolest, isegi pühendumata žanrilistele keerdkäikudele on silmanähtav, et selles valdkonnas on akadeemiliselt uuritava ainese staatuse saavutanud õuduslood loomadest, õnnetusjuhtumite, äri- ja igapäevaelu sündmuste, vempude, rumalate kokkusattumiste jms kirjeldused.

Tundub, et Jan Harold Brunvand on kogu sellest heterogeensest jutuainesest selgelt eelistanud nn fabliau legende. ${ }^{7}$ Üleloomuliku sisuga tänapäeva muistenditest tuntuimat Haihtuvat hääletajat peab J. H. Brunvand ebatüüpiliseks linnamuistendiks. Nii kindla sisuga üleloomulikke jutte on tema väitel linnalegendide hulgas ainult mõned (vt Brunvand 2000: 10). Erinevalt mitmetest teistest samalaadsete kogumike autoritest on ta neid siiani oma raamatutes veidi vältinud ja vähem esile toonud, paigutades nad näiteks niisuguste teemade alla nagu autolegendid, seks ja armastus. ${ }^{8}$

Ameerika Ühendriikide võrdlev-ajaloolist suunda iganenuks pidavate folkloristide ringkondades ja paiguti mujalgi suhtutakse J. H. Brunvandi ka kui kerge saagi tagaajajasse. Tema võis olla üks nendest, keda psühhoanalüütilise ja strukturalistliku lähenemisviisiga kaasmaalasest folklorist Alan Dundes ${ }^{9}$ silmas pidas, kui kirjutas muistendiuurijatest-liblikakollektsionääridest, kes koguvad liike ja alaliike ning jälgivad nende levikut, hüljates muistendi süvauurimise teed, näiteks psühholoogilise vaatenurga (vt Dundes 1971: 22).

Jan Harold Brunvandil on aastatega kogunenud tõesti tuhandeid informantide kirju, ajaleheväljalõikeid, suuliste versioonide 
üleskirjutusi ja uurijate artiklite koopiaid, mis kõik kokku dokumenteerivad sadu linnalegende. Tal on kujunenud oma korrespondentide võrk, kellega ta suhtleb põhiliselt elektronposti teel - huvilisi liitub nii ajakirjanike kui ka tema raamatute lugejate hulgast. Mõnda aega olid J. H. Brunvandi täita ka regulaarselt ilmuvad ajaleheveerud.

Uurija on mõne jutusüžee elukäiku jälginud aastaid, isegi aastakümneid. Tänapäeva muistendi uurija Paul Smith Newfoundlandist on avaldanud arvamust, et J. H. Brunvandi kui rahvaluuleteadlase kommenteerivast ja arvamust avaldavast häälest on saanud üks olulisi jutu leviku protsessis osalejaid (Smith 1992: 51). Viimase rolliga peavad arvestama kõik aktuaalse tänapäeva jutuainesega tegelevad folkloristid, kes meedias sõna võtavad või oma töid publitseerivad. Ühel hetkel võid avastada, et võib-olla olid sa ise see, kes mõnele jutule (või lausa käitumisele) eeskuju on pakkunud, eriti kui tegemist on näiteks niisuguse üldist ohtu ja ärevust tekitava haigusega nagu AIDS (vt näiteks EFA I 45, 91/2; Sikk 2000).

Jan Harold Brunvandi raamatutele on ette heidetud metodoloogilist ühekülgsust (vt Ellis 1989: 77-80), teisalt aga väärtustatud tema tööd kirjaühiskonna teadliku muistendilugeja kasvatajana (Dégh 2001: 86-94). Popkultuuri uurijad suhtuvad tema töödesse kui tänapäeva loojatele mõeldud varaaita, mida see kahtlemata ka kirjanikele, kunstnikele ja filmitegijatele on. New Yorgi ülikooli inglise keele professor Harold Schechter möönab, et peaaegu kõigile J. H. Brunvandi esimese raamatu (1981) lugudele on võimalik leida vasteid hiljutistest filmiversioonidest.

Lugu peab olema hea ja puudutama midagi olulist [---] alles selle järel loevad filmi puhul teised tegurid: tegelased, näitlejad, stiil, muusika. Muistendid ja mü̈̈did on järeleproovitud lood (Schechter 1988: 16).

Vaevalt et enamikule J. H. Brunvandi raamatu fabliau legendidest saab rajada terve filmistsenaariumi. Pigem leiavad need kasutamist kergemat vaheldust pakkuva sideainena muidu liiga tõsiseteemalises filmis, jutustuses või romaanis..$^{10}$

Tänapäeva muistendeid võib leida väga erinevates olekutes ja vormides. Tuntud juttude tekste, motiive, käitumis- ja suhtumismalle, interpretatsioone, neil põhinevat ikonograafiat ja kontseptsioone kohtab kogu tänapäeva kultuuris ja meedias. 


\section{Eda Kalmre}

Laia avalikkuse ette tõi Jan Harold Brunvandi linnalegendid mõjuvaim visuaalkunst, filmikunst. Kompaniis Columbia Pictures 1998. aastal vändatud õudusfilm Urban Legend

[---] ei võitnud küll ühtegi akadeemilist auhinda, polnud isegi äramärgitute hulgas, aga tõmbab kindlasti rohkesti avalikku tähelepanu tänapäevasele folklooriliigile, mis paelub nii uurijaid kui ka tavainimesi (Brunvand 2000: 205-207).

\section{Artiklikogumikust Heale jutule pole tõde takistuseks}

Peaaegu kakskümmend aastat pärast Haihtuva hääletaja esmatrükki ilmus Jan Harold Brunvandi raamat, mis eristub mõneti vahepealsetest laiale lugejaskonnale mõeldud kogumikest. Ainekäsitluse poolest on The truth never stands in the way of a good story (Heale jutule pole tõde takistuseks 2000) võrreldav autori esimese raamatuga. Kui Haihtuv hääletaja on uudne ja teedrajav monograafia, siis Heale jutule pole tõde takistuseks on autori esimene artiklikogumik, milles ta jäkab paljudes varasemates raamatutes avaldatud linnajuttude käsitlemist ja pakub ka uusi teemaarendusi. Paljud artiklid on välja kasvanud Ameerika Folkloori Seltsis, Tänapäeva Muistendi Uurijate Seltsi aastakonverentsidel või mujal peetud ettekannetest. Mitmed mainitud raamatu artiklid on varem lühendatud kujul ilmunud ajakirjas Western Folklore ja seerias Contemporary Legend.

Mainitud raamatust ei leia nii kergesti J. H. Brunvandi eelmistele raamatutele tunnuslikku huumorit ja kerget stiili. Need on seal küll olemas, aga varjatud. Kui tema varasemate raamatute adressaadiks oli lai lugejaskond samavõrra kui folkloristid, siis kõnealuse kogumiku mõned peatükid sisaldavad nii palju detaile ja detektiivitööd, ajalugu ja allikaid, et see raamat pole kindlasti kirjutatud üksnes meelelahutuseks.

Kogumik sisaldab kolmeteist juhtumi- või tüübikeskset uurimust. Käsitletud teemade ja juttude nimistu on mitmekesine. Siin vaadeldakse üldtuntud ja lausa klassikaks saanud linnajutte, mille arengut ja allikaid on autor aastakümneid jälginud, aga ka kitsama ringi lokaalsema levikuga lugusid. Järgnevalt lühike ülevaade kogumiku mitmekülgsest temaatikast. 
Artiklites "Mis on punane ja valge ja küpsetatud?" (What's Red and White and Baked All Over? $)^{11}$ ning “"Röstitud beebi” kui uus ameerika linnalegend" ("The Baby Roast" as a "New American Urban Legend") käsitletavad üldlevinud mikroahjulood on olnud autori tähelepanu all 1960.-1970. aastatest alates ja neid on ta avaldanud ka enamikus varasemates tekstiraamatutes (vt Brunvand 2000: 62-63; 1981: 117-122; 1989: 219-226).

Laibalõhna tõttu odavalt müüdud auto loo (Death Car) avaldamine Richard M. Dorsoni folklooriõpikus 1959. aastal ja selle edasine uurimine nii Richard M. Dorsoni kui ka teiste folkloristide teostes tähistab uut etappi tänapäevajutupärimuse uurimisel.

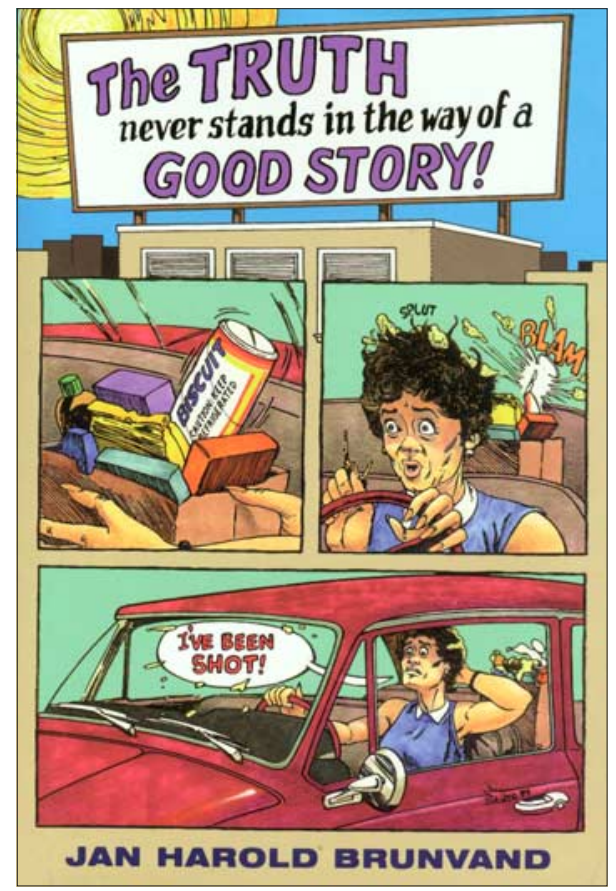

Jan Harold Brunvandi 2000. aastal ilmunud artiklikogumiku The truth never stands in the way of good story (Heale jutule pole tõde takistuseks) kaasautor on tema arvutispetsialistist poeg Erik Brunvand. J. H. Brunvand vaatleb seda peatükis "Richard M. Dorson ja linnamuistend" (Richard M. Dorson and the Urban Legend).

1995. aasta pika kuuma suvega seostuv sõnamängulise pealkirjaga jutt The Drain Brain, mis pilab hirmu võimu mõistuse üle, oli Ameerikas aktuaalne 1990. aastatel. Kui see humoorikas lugu levinuks Eestis, sobinuks selle pealkirjaks Hirmul on suured silmad. Jutu tuntuim versioon räägib tänapäeva linnakeskkonnas levinud hirmust ootamatus kohas välja ilmuva kurjategija ees. Kardetud kurjategija ja püstolilasu asemel paukus aga hoopis auto tagaistmel kuuma käes purunenud ja laiali lennanud küpsisepakk.

Paikkondlikku pajatust oimetuks löödud või oimetust teesklevast hirvest, kes hiljem autos jahimeest ja tema koera kimbutas, 


\section{Eda Kalmre}

käsitleb autor peatükis "Kas oimetuks löödud hirv või lihtsalt hirve trikk" (Was It a Stunned Deer or Just a Deer Stunt). Metsloomade "elluärkamine" kui kaval kaitsekäitumine on andnud ainet paljudele muinasjuttudele ja pajatustele, sest niisugune koomiline situatsioon on hea jutu tekkimise eeldus. Ka Mall Hiiemäe on kirjeldanud selliste lugude sündi ja toonud mitmeid analoogseid näiteid eesti jahimeeste traditsioonist (vt Hiiemäe 1969: 15-17, 72).

Lugu klounist ja laste unejutuonust, kes eetris kogemata ebasündsalt väljendus, vaadeldakse kirjutises "Bozol on aeg voodisse minna. Lugu klounist, kes rääkis lastele perverssusi" (Bedtime for Bozo. The Legend of the Clown who cussed the kids) annab edasi raadio- ja teleinimeste hirmu öelda töötava mikrofoni ja kaamera ees kogemata midagi kohatut. Eestis on laiemalt teada lugu ühe sünoptiku ilmaennustusse lipsanud lausest idast ei tule meile midagi head / idast ei ole meile kunagi midagi head tulnud, mis viitas Nõukogude Venemaa anastuspoliitikale Eesti suhtes. Jutu järgi olla sünoptik saanud esinemiskeelu raadios ja televisioonis.

Artiklis "Kustuta tuled!" Faksipärimuse fenomen" "Lights out!" A Faxlore Phenomenon) analüüsib autor samuti vägivallahirmust ajendatud lugu. 1993. aastal levitasid firmad, pangad, ülikoolid ja sõjaväeosad üle Ameerika faksi ja elektronposti teel justkui politsei ametlikul blanketil hoiatuskirja teedel tegutsevatest mõrtsukatest. Näiteks Silicon Valleys levis hirmulugu e-kirjades tohutu kiirusega. Kellegi osavalt sepitsetud nali väljus kontrolli alt, muutudes paljudele reaalseks hirmuks. Selle jutu käekäiku uurides ei jää autoril üle muud kui tõdeda, kui haavatav võib olla ühe lendu lastud kuulduse suhtes suur ja võimas Ameerika või inimühiskond tervikuna.

"Ilmkärakas, mida kuuldi kogu maailmas" (A Blast Heard round the World) räägib Eestiski tõsiloona võetud topeltõnnetust. Nali plahvatanud tualetis vigastusi saanud ja hiljem parameedikute käest maha pillatud patsiendist kuulub linnamuistendite klassikasse. Esmakordselt 1988. aastal Tel Avivi Jerusalem Postis ilmunud lugu levitasid hoolega kogu maailma uudisteagentuurid. See linnamuistend on näide ajakirjanduse ja suulise pärimuse vastastikustest mõjutustest ning tänapäeva muistendi erinevatest esitusviisidest (uudisena, libauudisena, naljana) pressis (Smith 1992: 45-53).

Paranormaalsetest nähtustest ja vaimudeilmast jutustavad kaks artiklit. Haihtuva hääletaja analoogi, lugu inimeste ilma naasnud vaimust vaadeldakse kirjutises "Folkloristid otsimas vaimu, kes otsib võimalust aidata surijat" (The Folklorists' Search for the Ghost in 
Search of Help for a Dying Person). Teaduse, religiooni ja paranormaalse vahekorda analüüsib lugu kadunud ajast "Ajaarvamisest puuduv päev" (The Missing Day in Time) analüüs. Jutt meenutab populaarset teleseriaali $X$-failid, kus teadusliku ja mütoloogilise (reaalse ja fantastilise) vahekord on niivõrd hästi segatud (vt ka Myhre 1997: 143-151), et on loodud nüüdisaja inimesele usutav lugu. J. H. Brunvandi käsitletud jutus on Ameerika kosmoseuurijad justkui tuvastanud tänapäevase planeetide seisu järgi, et ajaarvamises on läinud kunagi kaduma üks ööpäev. Nüüdisteaduse "avastust" aitab seletada Joshua raamat. Selle järgi olevat päike tõesti ööpäeva ühel kohal seisnud.

See legend kirjeldab, kuidas tänapäeva moodsaim tööriist arvuti - kinnitab piibli imet. Lugu levis aktiivselt erinevates versioonides fundamentalistidest kristlaste seas, aga selle juuri tuleks otsida nii trükitud kui ka suuliste vanemate pseudoteaduslike religioossete spekulatsioonide hulgast (Brunvand 2000: 137).

Lugu levis Ameerikas kettkirjana ja perioodikas, seda levitati ususektides ja räägiti suuliselt.

Kirjutises "Mõningaid militaarjuttude iseärasusi" (Some Oddities of Military Legendary) analüüsib J. H. Brunvand viit põhilist militaarjuttude kategooriat. Need on nn tagalalood, treeningulood, väeosade rännakulood, ellujäämis- ja tehnoloogilised lood. Laias laastus on üks osa sõduripärimust humoorikas, teine osa aga väljendab raske sõjaolukorra üleelamiseks vajalikke lootusi, ootusi ja mütoloogilisi kujutelmi.

Tänapäeva juttude kujunemist käsitledes arutleb J. H. Brunvand probleemide üle, mis tekivad, kui püütakse kindlaks teha, kas tegemist on väljakujunenud jutu või alles tärkava ja piirjooni võtva looga. Talle on saadetud ja ta ise on ajakirjandusest kogunud sadu tärkavaid jutuvõrseid, mis on üheks tõenduseks meediauudiste ja linnajuttude sarnasusest. On raske ennustada, missugune uudis leiab ümbertöötamist, kordamist ja lõpuks folkloriseerub. Erisus uudise ja linnajutu vahel ilmneb ehk ainult nende valikus, suulises levikus ja varieerumises, mitte niivorrd erinevates sisuelementides.

Viimase, kolmeteistkümnenda artikli "Heroiline häkker. Arvutiajastu legendid" (The Heroic Hacker. Legends of the Computer Age) on kirjutanud Jan Harold Brunvandi poeg Erik Brunvand. See on arvutiinimese sisemisest vaatepunktist kirjutatud lugu häkkerlu- 


\section{Eda Kalmre}

sest. Populaarne press kujutab häkkerit kohanematu, sotsiaalselt tõrjutud noorukina, ka võõrastesse saladustesse tungiva ja krediitkaardipettust kasutava kurjategijana jms.

Arvutispetsialistide hulgas on häkkeril teine positsioon: ta on ülendatud kangelaseks, nimetus häkker kõlab kui kompliment. Paiguti omistatakse talle lausa üleloomulikke ja isegi maagilisi võimeid. Arvutiinimeste seas ringlevad legendid geniaalsetest häkkeritest. 1980. aastatel levisid lood lausa üleinimlike programmeerimisoskustega Melist. On enesestmõistetav, et niisugused lood levivad erialastes infolistides ja e-kirjade teel. Lugu Melist on pikk poeem, täis arvuti- ja programmeerimisalaseid tehnilisi termineid ning selle valdkonna inimeste žargooni (vt ka Vesik 1996).

Raamatu kokkuvõttes rõhutab autor veel kord linnamuistendite elujõulisust ja asjaolu, et need on suutelised nii ajas kui ka ruumis laialt levima. Pole ühtki muud juttu, mis sisaldaks nii olulist teavet tänapäeva inimese mõistmiseks. Seepärast on loomulik, et nii kollane ajakirjandus kui ka akadeemilised väljaanded hoiavad sellel temaatikal silma peal, ammutades siit lisaandmeid või meelelahutust ning samas tõepärastades ja levitades ise neid jutte.

\section{Metoodikast, tõest ning kontekstist}

Kolmeteistkümnele eespool kirjeldatud juhtumikäsitlusele eelneb autori sissejuhatus, kus J. H. Brunvand meenutab oma uurijateed linnalegendide juurde ja olulisemaid tähiseid selle ainese uurimisel. Muidugi ei saa ta ka siin läbi materjali veel kord defineerimata ja termini ümber arutlemata.

Tegelikult sõnastab J. H. Brunvand sissejuhatuses ka oma uurijakreedo. Ta ei seagi endale kõrgeid eesmärke ega ürita eriti süvitsi minna. Tema arvates peab jutu analüüs põhinema võimalikult suurel hulgal tekstidel ja versioonidel. Oluline on jälgida jutu kujunemist ja arengut ning selleks sobivad kõik allikad, nii klassikalised (arhiiv ja suuline esitus) kui ka tänapäeva meedia ja Internet (Brunvand 2000: 8).

J. H. Brunvand ise loodab, et tema vaatenurgad, tehnika ja allikad aitavad samade juttudega tegelevaid uurijaid tulevikus ja harivad ühtaegu lugejat, õpetades, et ära usu kõike, mida kuuled. Tõepoolest, arvestades Ameerika Ühendriikide suurt lugejaturgu ning 
tema lahedalt kirjutatud käsitluste hulka ja läbimüüki, võib seda osa autori eesmärgist pidada täidetuks.

Minu lähenemine on üldiselt ajalooline ja võrdlev, sest ma olen veendunud, et interpretatsioonid ja analüüsid peavad põhinema suurel andmestikul, millele lisandub võimalikult täpne informatsioon iga jutu ajaloo ja kujunemise kohta. Selleks, et illustreerida, kuidas lood minu kollektsiooni kogunevad ja kuidas populaarsete versioonide dokumenteerimisest kujunevad interpretatsioonid, kasutan sageli esmast allikat ja taastan kronoloogilise struktuuri. Alles siis saab hakata môtteid môlgutama selle üle, millised sotsiokultuurilised mudelid on tegelikult "Röstitud beebi" temaatikas, miks on kalli retsepti järgi valmistatud kook punane, mida räägib uuem kuritegeliku jõugu legend meie aja hirmudest ning kuidas kirjeldab pseudoteaduslik "evangeelne muistend" teaduse ja religiooni vahelisi pingeid (Brunvand 2000: 8).

J. H. Brunvand ei ole esimene, kes kasutab võrdlev-ajaloolist meetodit tänapäeva linnalegendide uurimiseks. Sama suunda viljelesid tema oppetaja Richard M. Dorson ja Soome folklorist Leea Virtanen, kes pidas olulisteks alusuuringuid ka niisuguste tänapäevaste žanride puhul nagu linnajutud, anekdoodid, käibetõed jm. Leea Virtanen pidas näiteks vajalikuks tüübiindeksite koostamist edasiste uuringute tarvis. Just tema leidis Jan Harold Brunvandi motiiviindeksis ära toodud 300 jutumotiivist ligemale pooltele Soomes vasted. See oli tema arvates oluline, tõestamaks nende traditsioonilisust nii tänapäeva Ameerika kui ka Euroopa jututraditsioonis (vt Virtanen 1993: 255-271). Leea Virtanen iseloomustab uurija lähenemisviisi:

Kriteerium, kas töö on teaduslik või mitte, põhineb mitte niivõrd tulemustel, kuivõrd informatsiooni valikul, organiseeritusel (liigendatusel) ja analüüsil. Kogumine, mille taga on põhjalikkus ja ettevaatlik (hoolikas) allikakriitika, materjali esitus nii, et iga uurija saaks jälgida argumente ja korrata analü̈̈si ning mõista lõpptulemust - see kõik oli tü̈̈piline varasematele Soome koolkonna folkloristidele (Virtanen 1993: 270).

Tegelikult oleneb ju kõik sellest, missugused küsimused ja ülesanded töö kirjutaja endale seab. Jan Harold Brunvandi lähenemine on avatud, ei absolutiseeri, vaid pakub palju võimalikke tähendusi, 


\section{Eda Kalmre}

mille vahel lugeja ise peab valima. Üks põhjalikumaid ja paremaid käsitlusi mainitud raamatus on artikkel jututüübist Röstitud beebi. J. H. Brunvand on teinud siin tõeliselt üksikasjaliku võrdleva analüüsi, esitades nii erinevad tõlgendused (selles artiklis erinevalt teistest ka rohkem jutustajate omi) kui valgustades igakülgselt jutu rääkimise tagapõhja. Ta teeb põikeid tänapäeva tehnoloogiasse (mikrolaineahjude uudsus ja kahjulikkus) ning tutvustab mitmete erinevate uurijate meditsiinist, psühhoanalüüsist või sotsiaalteadustest tulenevaid tõlgendusi. Paralleelversioonide otsingutel põikab autor vist küll igasse maailmajakku ja mitmete kultuuride juurde Ameerikast Uus-Ginea ja Mikroneesia saarestikuni.

Kõik artiklid on kirjutatud enam või vähem sama meetodilist skeemi järgides. Esmalt on ära toodud juttude levik, areng ajas ja ruumis, tavaliselt ka jutu folkloristlik tagapõhi, peamised versioonid ja arendused. See osa sisaldab võrdlusi teiste ainevaldkondadega (meditsiin, psühholoogia) ja sama motiivi otsinguid ajas läbi mitme žanri. Artiklites on rohkesti vihjeid erinevate autorite käsitlustele ja muidugi allikaviiteid.

Enamasti viitab J. H. Brunvand nendele ilma omapoolse arvamuse või kriitikata, vaid üksikutel juhtudel vaidleb ta osundatud autorile vastu. Sallivus kõigi võimalike tõlgenduste suhtes ongi põhiline etteheide tema käsitlustele. Tundub, et ta lepibki suurema osa väidetega, välja arvatud ehk liiga otsesed ja rabedad psühhoanalüütilised tõlgendused. Näiteks keeldub ta jagamast Gary Alan Fine'i arvamust, et naise auto tagaistmel laialilennanud küpsisepakist tulnud pauk võib olla seksuaalne metafoor:

Arvan, et mõnikord ongi küpsisetuutu lihtsalt küpsisetuutu (Brunvand 2000: 27).

Iga meetodi väärtus on piiratud. Julgen arvata, et ainuüksi psühholoogiale, semiootikale vms tuginev jutuanalüüs on veel piiratum kui edasist laia arutelupõhja ja perspektiive pakkuv võrdlev-ajalooline lähenemisviis. Kui ei oleks läbi töötatud pindmisi kihte, ei saaks minna sügavuti, kuid näiteks psühhoanalüütiline lähenemine muistenditele on sageli moeküsimus, mis avab küll uusi silmapiire, aga osutub tihti ikkagi silmapetteks. Lõpuks on kõik metoodikad vajalikud, kui nad pakuvad uusi vaatenurki, tõlgendusi või võrdlusainet.

Enamikus käsitlustest on J. H. Brunvand tõeliselt andunud esimese jutustaja ja/või jutustuse algversiooni ja tõepära otsija. Seda 


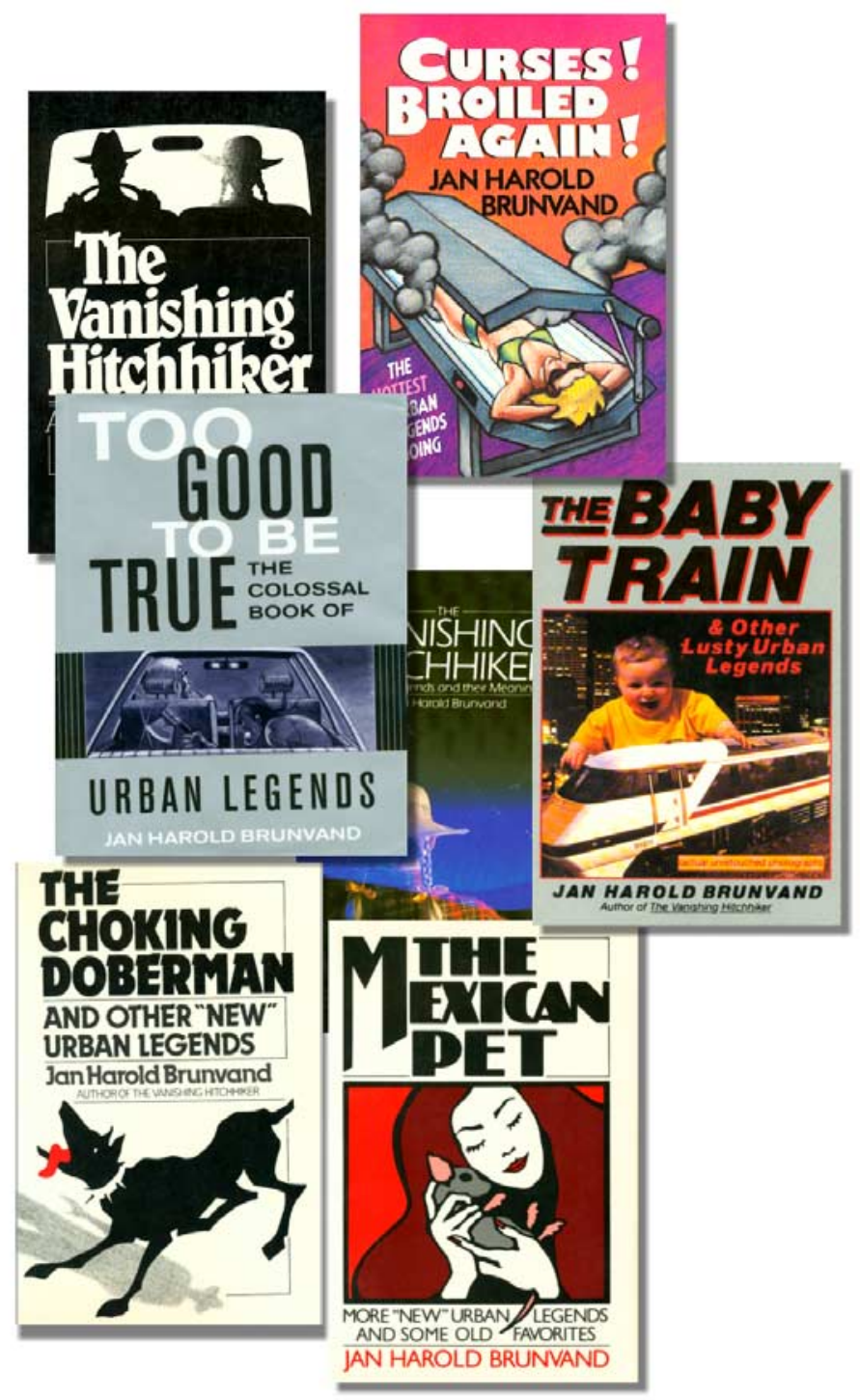

Valik Jan Harold Brunvandi linnalegende käsitlevaid raamatuid, mis on Ühendriikides saanud lausa bestselleriks: The Vanishing Hitchhiker (1981); Curses! Broiled Again! (1989); Too Good to be True (1999); The Vanishing Hitchhikeri üks kordustrükke; The Baby Train (1993); The Choking Doberman \& Other "New" Urban Legends (1984) ja The Mexican Pet (1986). 


\section{Eda Kalmre}

tehes on ta ühendanud võrdlev-ajaloolise lähenemise muistendi põhiküsimusega: kas räägitakse tõesti aset leidnud sündmusest.

J. H. Brunvand jõuab selgusele, et algupära või algversiooni otsida pole kuigi lihtne. Tänapäeva muistendi tekkimine ei seisne ainult mingi erilise sündmuse faktide ümbertöötamises. Tegemist võib olla pigem protsessiga, kus kaks või enam sarnast (ajaloolist) sündmust folkloriseeruvad ja levivad, üldistudes fiktsiooniliste variantide kogumis (Brunvand 2000: 19).

Kolmeteistkümnest artiklist ainult ühes kannab J. H. Brunvandi väsimatu detektiivitöö positiivseid vilju. Jahimehe autosse tõstetud oimetu hirve loo puhul leiab ta lõpuks nii jutu algversiooni kui ka selle põhjuseks olnud tõsielusündmuse. Keegi mees helistas tõesti telefoniautomaadist politseijaoskonda, kirjeldas täbarat olukorda, millesse ta teadvusele tulnud hirve tõttu oli sattunud, ja palus abi. Lugu tuli ilmsiks ja hakkas levima tänu sellele, et valves olnud politseinik lindistas kõne ja suunas selle ka kolleegidele kuulata. Tänu suust suhu levimisele ja kahele ajaleheartiklile lülitus jutt kohalikku traditsiooni, kuid moondus suulise leviku, lindistuse halva kvaliteedi ja sellest tehtud kehvade koopiate tõttu.

Teiste J. H. Brunvandi käsitletud juttude ja jututsüklite puhul on seos konkreetse juhtumiga ainult tõenäoline, mitte tõene.

\section{Kokkuvõtteks}

Kuigi tegemist on folkloristi kahtkümmend viimast linnamuistenditega tegelemise aastat kokku võtva raamatuga, ei ole tal teoreetilises lähenemises lisada midagi olulist. Pigem on autor viimistlenud täiuslikkuseni oma juba varem rakendatud metoodika. Kindlalt ühel teoreetilisel teel püsimine viitab ennekõike Jan Harold Brunvandi küpsele teadmisele sellest, mida ta teadlase ja uurijana teeb ning öelda tahab.

Tundub, et linnamuistendite kohta on nüüd kõik juba korra öeldud ja jutusüžeede entsüklopeediagi koostatud. Kahekümne aasta möödudes jõuab J. H. Brunvand samale seisukohale Newfoundlandi ülikooli professori ja Rahvusvahelise Tänapäeva Muistendi Uurimise Seltsi ühe juhi Paul Smithiga, kes juba kümmekond aastat varem tuli välja kartusega meedia standardiseerivatest mõjutustest. Juba 17., 18. ja 19. sajandil, kui rahvaluuletekstid ilmusid efemeersete trükiste ja rahvaraamatukestena, hakkasid need mõju- 
tama suulist traditsiooni. Toimus jutupärimuse standardiseerumine. 1992. aastal väitis Paul Smith, et pidevalt meedia tähelepanu all olevate tänapäeva muistenditega võib juhtuda sama, aga ehk siiski ei juhtu, sest muistendid ei ole kõvad uudised, vaid nn pehmed uudised, mis käsitlevad siiski ainult inimelu tekstuuri ehk sisemisi kudesid (Smith 1992: 66-67).

ISCLRi konverentsil Sheffieldis 2002. aasta suvel oli avaliku arutelu all Jan Harold Brunvandi veidi varem Ameerikas peetud nii poolt- kui ka vastuhääli pälvinud ettekanne Kaduv linnalegend (The Vanishing Urban Legend). J. H. Brunvandi seisukoht oli, et linnamuistendit ei jutustata suuliselt enam nii innukalt ja üldiselt kui 1960.-1980. aastatel ehk sellest ajast peale, kui paljud neist süžeedest on üle võtnud popkultuur, televisioon, reklaam, film ja eriti Internet.

Kõik, mis ma võin öelda, on mu isiklik kogemus - inimesed ei räägi tänapäeval enam nii palju linnamuistendeid ega mõtle neid enam nii palju välja, selle asemel saadavad nad neid lihtsalt e-kirjades veidi muudetuna edasi (Brunvandi 2003; vt ka Foaftale News 53).

Mõlema folkloristi eelmainitud sõnavõttudes oli kuigivõrd nostalgiat. Esialgse emotsiooni ajel võrdsustasid nad pärimuse standardiseerumise allakäiguga, unustades, et seegi on loomulik protsess, mis märgib ennekõike uusi kasutusvaldkondi. Traditsioon ei ole muutumatu ja standardiseerub ainult teatud piirini. Ilmselt on aeg loobuda tänapäeva muistendite puhul puhtfolkloristlikust rõhuasetusest ja keskenduda rohkem ajakirjanduse ja kultuuri uurimisele, mis aga sugugi ei tähenda, et põnevad juhtumikesksed käsitlused võiksid päriselt unustusse jääda.

Jan Harold Brunvand ei ole end kauaks nostalgiameeleoludest mõjutada lasknud, nagu ta pole ka avalikult tunnistanud, et tema enda linnamuistendite alal kirjutatu on aidanud kaasa vähemalt ameerika tänapäeva muistenditraditsiooni ühtlustumisele.

Emeriitprofessorist "Linnalegendide isa" Jan Harold Brunvand on omal alal endiselt tegev ja vormis, suusatab ja koostab uut raamatut hirmujuttudest. Peale selle kavatseb ta 2003. aasta juunis Newfoundlandis Corner Brookis peetaval järjekordsel ISCLRi koosolekul rääkida sellest, kuidas Ameerika meedia tarvitab ja rakendab terminit linnamuistend, muutes selle mõnikord linnamüüdiks, ${ }^{12}$ 


\section{Eda Kalmre}

sest linnamuistendid pole veel kuhugi kadunud ja heale jutule pole tõde takistuseks.

\section{Kommentaarid}

${ }^{1}$ Leea Virtanen oli soome folklorist, Helsingi ülikooli rahvaluuleprofessor ja estofiil, keda sidusid Eestiga mitmed uurimistööd ja paljud isiklikud kontaktid. Tema mitmekülgsed huvid ulatusid regivärsist tänapäeva pärimuseni. Lastefolkloor, linnajutud, moodne maagia, telepaatilised kogemused ja argiuskumused olid paljude Leea Virtaneni kaasaja folkloori käsitlevate uurimuste ja monograafiate materjaliks.

2 Üheks innustajaks võib pidada ka Leea Virtaneni enda 1972. aastal Fr. R. Kreutzwaldi nimelise Kirjandusmuuseumi rahvaluuleosakonna üllitiste seeria 8. numbris ilmunud "Juhendeid lastefolkloori kogumiseks" (Virtanen 1972).

${ }^{3}$ Kaasaegse ainese uurimisele eelnes kogumistöö. Esimesed küsitluskavad valmisid alles 1990. aastate alguses. Arhiivimaterjalide laekumise järgi on aga tuvastatav, et tänapäeva muistendiainest hakati arhiivi koguma juba 1980. aastate keskel.

${ }_{4}^{4}$ Andmed Jan Harold Brunvandi isiku ja karjääri kohta siin ja edaspidi pärinevad tema kirjast (27. jaanuarist 2003) käesoleva artikli autorile Eda Kalmrele (Brunvand 2003).

${ }^{5}$ Andmed peamiselt J. H. Brunvandi kirjast E. Kalmrele (Brunvand 2003).

${ }^{6}$ Katkend J. H. Brunvandi kirjast E. Kalmrele (Brunvand 2003).

${ }^{7}$ Fabliau legend on lühike humoorikas narratiiv, mille keskmes on mingi intriig ja mille käigus eirab üks jutu tegelane mõnd sotsiaalset tabu. $\mathrm{Nt}$ jutus Alasti üllatus peol püüab ülemus flirtida oma sekretäriga, jutus Eestlane sõi ära neegri toidu elatakse aga välja taunitav rassivaen (vt Ellis \& Mays 1994: 1).

8 Jutu juhtmotiiviks on siiski kokkupuude kummitusliku olendiga (vt ka Kalmre 1996: 150).

${ }^{9}$ Alan Dundes töötab Berkeleys California ülikoolis antropoloogia osakonna folkloristikaprofessorina. Ta on üks tänapäeva novaatorlikumaid folkloriste, kelle spetsiaalne huvi ja poolehoid kuuluvad strukturalismile ja psühhoanalüüsile.

${ }^{10}$ Näiteks muidu tõsises filmis, peredraamas Teekond olematusest (USA 1992) on episood, kus isa ja poeg panevad ühe naisterahva korteris põrandakatet. Lõpuks on kõik valmis ja mehed tunnevad rõõmu tehtud tööst. Korraga märkab isa, et vaiba all on mühk. "Tuleb siit lahti võtta," arvab 
isa. "Jätsid oma suitsupaki sinna alla," ütleb poeg ja kolgib kühmu tasaseks. Tööriistu kaubikusse viies märkab poeg seal isa suitsupakki. Tuppa tagasi tulles küsib ta isalt, mitu suitsupakki sellel kaasas oli. "Üks," vastab isa. Nüüd kerkivad mõlemate pilgud korteri perenaise viirpapagoi puuri suunas, mis on... tühi (Kanal 2, 11. mai 2002).

${ }^{11}$ See on kogu maailmas tuntud lugu koogist või küpsistest, mille retsepti omandamise eest pahaaimamatul külastajal tuleb hiljem hirmpalju maksta. Pettunud külastaja levitab kättemaksuks retsepti tasuta kõigile oma sõpradele ja tuttavatele. Eestis levis nali meedia ja Interneti vahendusel 2000. aastal (vt ka Mõistlik 2000). Kohalikus kontekstis oli toidukohaks Tallinna restoran Võitlev Sõna, ohvriks pankur ja ärimees Rain Lõhmus.

${ }^{12}$ Andmed J. H. Brunvandi kirjast E. Kalmrele (Brunvand 2003).

\section{Kirjandus}

\section{Käsikirjad}

Brunvand, Jan Harold 2003. Kiri Eda Kalmrele 27. jaanuarist.

Eesti Rahvaluule Arhiivi EFA - käsikirjaline kogu.

\section{Trükised}

Bennett, Gillian \& Smith Paul 1993. Contemporary Legend: A Folklore Bibligraphy. Garland Folklore Bibligraphies 18. London \& NewYork: Garland Publishing.

Brunvand, Jan Harold 1981. The Vanishing Hitchhiker: Urban Legends and their Meanings. New York \& London: Pan Books.

Brunvand, Jan Harold 1989. Curses! Broiled Again! The Hottest Urban Legends. New York \& London: W. W. Norton \& Company.

Brunvand, Jan Harold \& Brunvand, Erik 2000. The Truth Never Stands in the Way of a Good Story. Urbana \& Chicago: University of Illinois Press.

Dégh, Linda 2001. Legend and Belief. Bloomington: Indiana University Press.

Dundes, Alan 1971. On the Psychology of Legend. Hand, Waylon D. (toim). American Folk Legend: A Symposium, 22. Berkely: University of Californian Press, lk 21-36. 


\section{Eda Kalmre}

Ellis, Bill 1989. The Vanishing American Legend: Oral Narrative and Textmaking in the 1980s. Review Article. Lore \& Language VIII: 2, lk 75-102.

Ellis, Bill \& Mays, Alan E. 1994. Art Linkletter and the Contemporary Legend. Foaftale News 33/34, lk 1.

Foaftale News 53 (FTNi kodulehekülg: http://users.aber.ac.uk/mikstaff/).

Hiiemäe, Mall 1969. Üks jahimees läks metsa. Tallinn: Eesti Raamat.

Kalmre, Eda 1996. Vorstivabrikutest kassitoiduni ehk mõnda linnalugudest. Mare Kõiva (toim) Mängult-päriselt. Tänapäeva folkloorist II. Tartu: Eesti Rahvaluule Arhiiv \& Eesti Keele Instituut, lk 136-155.

Mõistlik, Anu 2000. Rain Lõhmus maksis koogiretsepti eest 40000 krooni? SL Õhtuleht, 4. aprill.

Myhre, Margareta Magnus 1997. The truth is out There. Nord Nytt 66/67, lk $143-151$.

Schechter 1988. The Bosom Serpent. Folklore and Popular Art. Iowa City: University of Iowa Press.

Sikk, Rein 2000. Aids ajab liikvele katkujutud. Eesti Päevaleht. 11. oktoober (vt ka Eesti Päevaleht, 13. juuni 2002; http://www.epl.ee/artikkel. php?ID=207522\&P=1).

Smith, Paul 1992. Read all about it! Elvis eaten by drug-crazed giant alligators. Contemporary legend and the popular press. Contemporary Legend 2. Sheffield: Sheffield Academic Press, lk 41-70.

Vesik, Sander 1996. Cyber...? Küber! (või oli see kübar?) Janika Oras (toim). Vaga Vares. Pro Folkloristica IV. Tartu, lk 122-131.

Virtanen, Leea 1993. Is the Comparative Method out of Date? Michael Chesnutt (toim). Telling Reality. Folklore Studies in Memory of Bengt Holbek. NIF Publications 26. Copenhagen \& Turku: Nordic Institute of Folklore, lk 255-271.

Virtanen, Leea 1972. Juhendeid lastefolkloori kogumiseks. Rahvapärimuste koguja 8. Tartu: Fr. R. Kreutzwaldi nimeline Kirjandusmuuseum, lk $12-16$.

Virtanen, Leea 1987. Varastettu isoäiti: Kaupungin kansantarinoita. Helsinki: Kustannusosakeyhtiö Tammi. 